\title{
消化器疾患の内視鏡治療 $*$
}

\author{
司会 浜松医科大学第一内科架金栄藏 \\ 司会 自治医科大学消化器内科栄村健 \\ 司会者のことば
}

内視鏡下の治療は，侵襲の少なさ，入院期間の 短縮，美容的な利点など，QOL (quality of life) の面で従来の開腹手術より多くの優れた点を有し ているため, 近年急速に進歩, 普及している. 本 シンポジウムでは現在もっとも広く行われている 消化管出血, 食道・胃静脈溜, 胃抢よび大腸早期 癌, 胆石などに対する内視鏡下治療について, 現 状とその問題点を明らかにし，さらに各演者の成 績に基づいて将来の展望を行った。

消化管出血の内視鏡下止血は，これにより消化 性潰湢の手術が激減したことからも明らかなよう に大きな成果をもたらした，止血法には発表にも あったように多数ある。通常の出血に対してはい ずれも高い止血率が得られるが，重篤な基璴疾患 を有する場合の出血にどのように対応するかが もっとも大きな問題である。胃・食道静脈瘤の内 視鏡的治療も静脈瘤出血死を低下させる点できわ めて効果的である。ここでも硬化片には数種類あ りどれをどのように用いるかにはまだ議論があ
る。早期癌の内視鏡治療は粘膜切除法 (EMR) の 導入によって飛躍的に拡大された，胃と大腸では その適応はほほ同様であるが，今後適応拡大が一 層検討されて行くことになろう。胆石症に対する 腹腔鏡下胆䙵摘出は本講演にもあるようにル ティーンの手技となった。

さてこのような内視鏡的治療が従来の治療法と 比べて経済性でも優れているには，合併症なく治 療を完了することが不可欠であることが本シンポ ジウムで示された。内視鏡下治療は通常の検查に 比べ手技が複雑となり偶発症の発症頻度が高くな ることは避けられない。また癌に対する内視鏡治 療の適応は常に人道的立場に立って決定されるべ きであることはいうまでもない。このような点を 充分認識し，患者にとってメリットのきわめて多 いこの内視鏡下治療がますます普及進歩すること を願っている．本シンポジウムがその一助となっ たとしたら幸いである。

*本シンポジウムは1996年 4 月11日 横浜市西区みなとみらい1-1-1 国立横浜国際会議場にて行われた。 